\title{
Variations in the viability and macromolecules concentration of E. granulosus protoscolices isolated from ruminants consequence treatment with Nigella sativa seed's oil (In vitro study)
}

\author{
M.Q. Yahya \\ Department of Clinical Laboratory Science, College of Pharmacy, Mosul University, Mosul, Iraq \\ Email: pharm.maymona@gmail.com
}

(Received June 5, 2018; Accepted October 10, 2018)

\begin{abstract}
The aim of the present study was to investigate the scolicidal activity of Nigella sativa seed's oil concerning the viability in vitro and biomolecules content (carbohydrates, proteins and nucleic acids) of Echinococcus granulosus protoscolices. Protoscolices were aseptically aspirated from cysts of livers and lungs (naturally infected) which eradicated from goats and sheep that had been slaughtered at Mosul local abattoir / Nineveh / Iraq from September 2017 to May 2018. Various concentrations of $N$. sativa seed's oil $(20$ to $60 \mu \mathrm{l} / \mathrm{ml})$ were applied on special time interval (5-40min). Viability of protoscolices was checked using vital stain $(0.1 \%$ aqueous eosin). Concentration of carbohydrates, proteins and nucleic acids (DNA and RNA) were estimated after treating the protoscolices with $\mathrm{LC}_{50}$ of the seed's oil $(40 \mu \mathrm{l} / \mathrm{ml})$ comparing with untreated group. It is revealed that mortality rate of protoscolices, those were treated for 10 minutes with $40 \mu 1 / \mathrm{ml}$ and $60 \mu 1 / \mathrm{ml}$ of Nigella sativa oil, were approximately $50 \%$ and $100 \%$ respectively. Viability $\%$ of protoscolices treated with $20 \%$ hypertonic saline solution for 5 minutes was $43 \%$, whereas, $16 \%$ of protoscolices were viable when treated with $60 \mu 1 / \mathrm{ml}$ of seed's oil at the same time. The experiments detect concentration and time-dependent scolicidal effect of $N$. sativa seed's oil on the E. granulosus protoscolices. Mean concentrations of carbohydrates, proteins and nucleic acids (DNA and RNA) were significantly higher at $\mathrm{P} \leq 0.05$ in control group $(62.6 \mu \mathrm{g} / \mathrm{ml}, 31.0 \mathrm{mg} / \mathrm{dl}$ and $(23.4$ and $82.9 \mu \mathrm{g} / \mathrm{ml}$, respectively) than that found in $\mathrm{LC}_{50}$ treated protoscolices $(58.3 \mu \mathrm{g} / \mathrm{ml}, 15.3 \mathrm{mg} / \mathrm{dl}$ and $(18.19$ and $64.48 \mu \mathrm{g} / \mathrm{ml}$, respectively). The study showed that oil extract of $N$. sativa seeds has a significant $(\mathrm{P} \leq 0.05)$ clear impact in reducing viability of $E$. granulosus protoscolices, as well as, mean concentrations of its biomolecules which may open away for further experiments about scolicidal validity of $N$. sativa seeds oil in vivo.
\end{abstract}

Keyword: Nigella sativa, E. granulosus, seeds oil, protoscolices, biomolecules. Available online at http://www.vetmedmosul.com

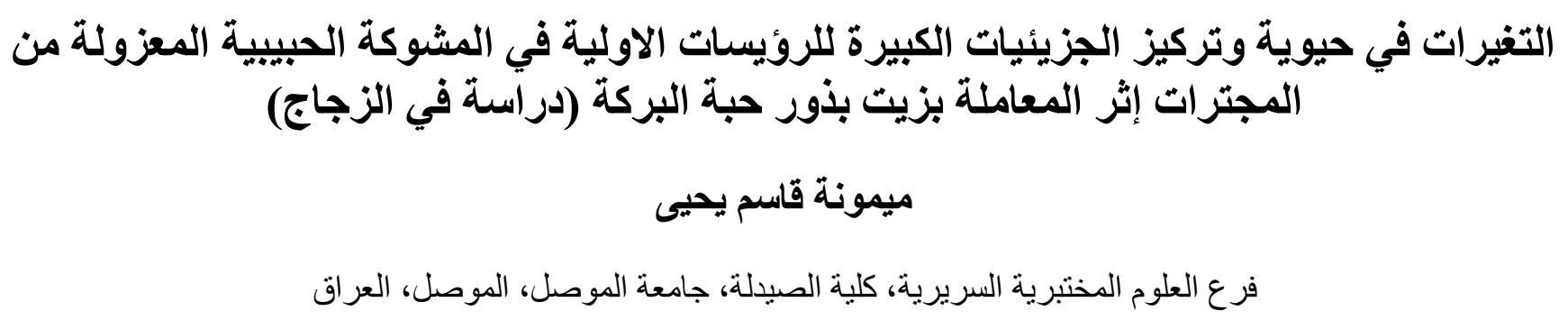

إن الهدف من البحث الحالي لمعرفة التأثثر القاتل لزيت حبة البركة (الحبة السوداء) على حيوية وتركيز الجزيئات الكبيرة

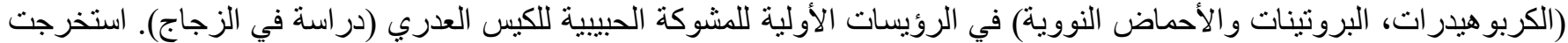

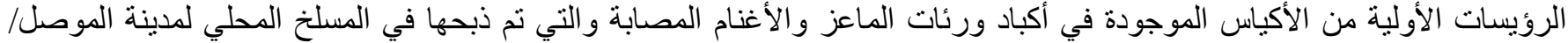

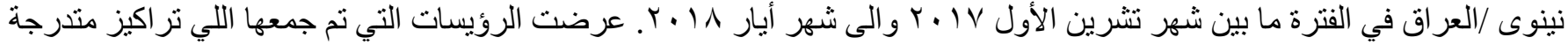




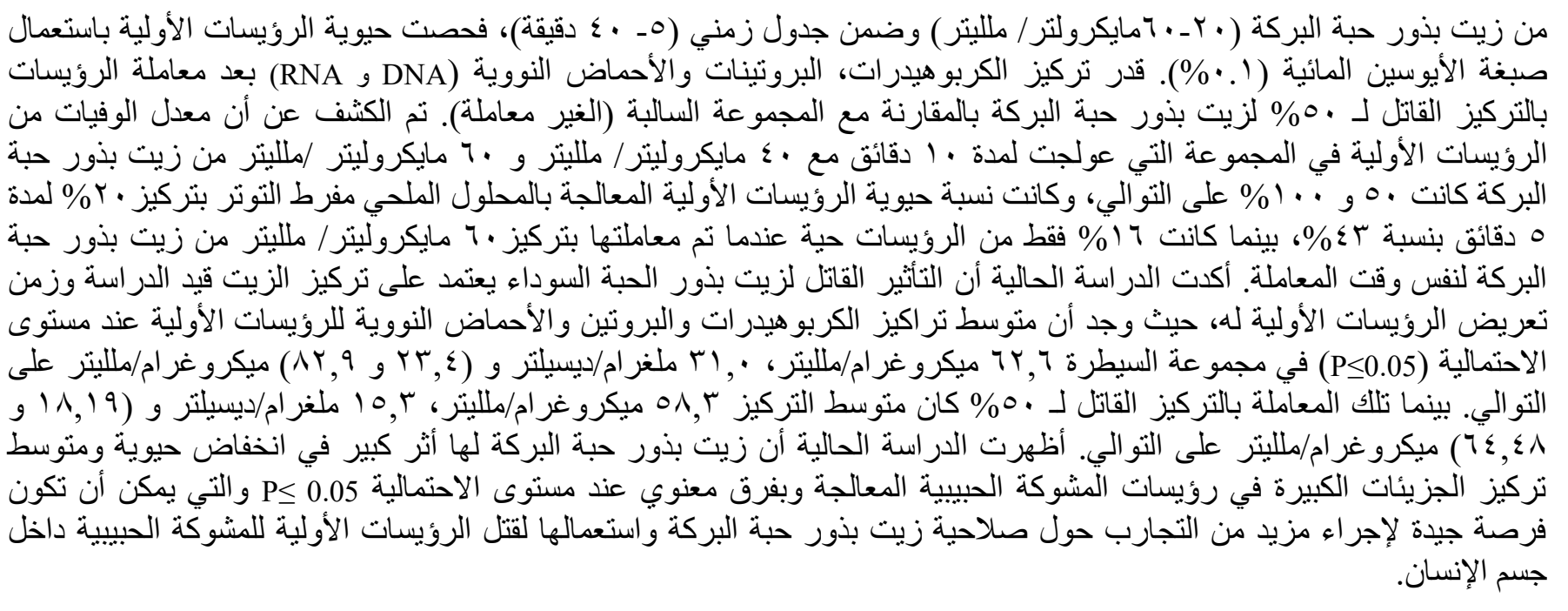

\section{Introduction}

Echinococcosis is a well-known anthropozoonosis that is endemic in many regions of the world. It's one of the most important neglected parasitic diseases and has been identified as universal popular health problem especially in developing regions including Iraq (1). Hydatidosis may cause serious morbidity and death (2). Man, and grassing animals as intermediate host which have encysted larval stage (the hydatid cyst), dogs and other canines may act as final host in which adult cystoda inhabits small intestine. Man may get infection when ingesting ova with contaminated food or fluids (3). Number and localized of the cyst, general condition of the patient, the surgeon's experience and the presence of special services like intensive care unit was the main factors that affect the choice of therapy (4). Surgical removal of hydatid cyst remains the preferred choice $(5,6)$. Furthermore, chemotherapy with benzimidazoles groups and PAIR (puncture, aspiration, injection, and respiration) are recommended as alternative treatments to surgery, especially for the patients who cannot tolerate surgery and to decrease the risk of intraoperative spillage of the cyst contents (protoscolices) $(7,8)$. Subsequently recurrence of cystic echinococcosis and secondary infection, which is observed in about $10 \%$ of the postoperative cases, the use of effective scolicidal agents are essential $(9,10)$.

Continuous trial to find agents those have high scolicidal effects in a shortest time to be used in surgery to prevent recurrence and secondary hydatidosis infections (8). Antihydatidosis agents like hypertonic saline, ethanol, silver nitrate, cetrimide and others used but have many serious adverse effects like liver necrosis, methemoglobinemia and sclerosing cholangitis (11). Therefore, developing new scolicidal agents with higher efficacy and less or no local or systemic adverse effects is necessary for treating hydatid cysts infections. Natural plant derivative has been widely used as antimicrobial agents either in folk medicine or as additive. As for hydatidosis infection, discovery of a novel scolicidal agent that has high efficacy against the parasites with low side effects is still the most important concern to eradicate the infection as reported by the World Health Organization (12). Specification of reliable scolicidal agents include the potency at lesser concentration in shortest time, the ability to permanents in the cyst fluid, minor toxicity, more complain to use and less side effects (13).

The most common chemotherapy used as antiecchinococcus agents is albendazole which is proved to have some adverse effects like poor solubility in gastrointestinal (GI) tract that is resulted in low drug concentration in liver, furthermore, encephalitis syndrome, influenza-like syndrome, allergic purpura, and drug rash (14), other researchers reported echinoccocal resistance to albendazole $(14,15)$. Thus, there is an urgent need for new therapeutic strategies toward creative scolicidal agents that have rapid and complete inhibitory effects and few side effects. Many researchers focused their efforts to use natural products specially plant extracts as antimicrobial agents which is found to have considerable effective efficacy, validity and have low cost (16).

Nigella sativa Linn. (Ranunculaceae) or black seed commonly grows in many places of the world (Western Asia, Middle East, North Africa and Southern Europe). It has been recognized as one of the most popular herbs in many parts of the ancient world, which was used in folk medicine to help in cure different diseases like cough, dizziness, headache, hypertension, eczema, bronchitis, fever and diabetes in worldwide (17), in addition, to their nutritional and healthcare benefit for humans (18). Many 
reports referred to the antioxidant, antitumor, immunepotentiation, anti-asthmatic and neuroprotective activities of $N$. sative seeds $(17,19)$, other studies revealed the antiinflammatory, general antimicrobial activities of $N$. sativa and its derivatives (20-22). Such pharmacological effects have been related its anti-inflammatory effects due to the presence of main active constituents that include thymoquinone (TQ), dithymquinone (DTQ), thymohydroquinone, dithymquinone (DTQ) and thymol (23). The cyst fluids and protoscolices contain biochemicals such as carbohydrates, proteins, lipids, vitamins, electrolytes and trace elements that may have role in the metabolism and growth of unilocular hydatid cyst (24). The carbohydrates of the protoscolices are glycogen, trehalose, glucose and alkali stable carbohydrates of particular interest was the detection of sucrose in both protoscolices and fluid (25). Proteins are the most important organic constituents of living things including cestode and play an important role in energy production. In the development process, various agents such as protein is required for the synthesis of ATP (26). The proteins of cyst fluid were mainly albumin and globulin, the latter having always double the concentration of the former (25).

Therefore, the aim of the present study is to estimate the scolicidal efficacy of $N$. sativa seed's oil against $E$. granulosus protoscolices and to evaluate its effect on the biomolecule contents of protoscolices compared with nontreated (negative control).

\section{Materials and methods}

\section{Collection of plant materials}

The seeds of $N$. sativa were purchased from local market in Mosul city. The identity was confirmed by Dr. May TH. Al-Wattar, Botanist, College of Science, Mosul University, Mosul, Iraq.

\section{Parasite source}

Fresh hydatid cysts were eradicated from livers and lungs of infected goats and sheep which had been slaughtered at Mosul local abattoir, Nineveh - Iraq. They were wrapped carefully in clean plastic bags, and carried to the microbiology laboratory at the Department of Clinical Laboratory Science, College of Pharmacy, University of Mosul where protoscolices were extracted.

\section{Preparation of Protoscolices extract}

Protoscolices (PSC) were aspirated according to Smyth (27). The outer surfaces of the cysts were sterilized with $70 \%$ ethanol before being dissected and withdrawn fluid sac by a $50 \mathrm{ml}$ syringe (suitable capacity), the aspirated fluid aseptically transferred into a flask. The cysts then washed from inside with Phosphate buffer solution (PBS) $\mathrm{pH}$ of 7.2, transferred to siliconized test tubes, underwent washing process and centrifuge two times per $3000 \mathrm{rpm}$, take the precipitation which contain the protoscolices with concentration of $7500 \mathrm{psc} / \mathrm{ml}$ (27). Viability of the protoscolices was accomplished by investigating peristaltic movement of the organism, flame cell and impermeability to the vital stain $(0.1 \%$ aqueous eosin) under the light microscope. Take $2 \mathrm{ml}$ of protoscolices suspension (15000 PSC) for the treatment study.

\section{Evaluation of lethal concentration $50\left(\mathrm{LC}_{50}\right)$ and lethal concentration $90\left(\mathrm{LC}_{90}\right)$ of Nigella sativa oil extract to $E$. granulosus protoscolices}

$20 \mathrm{~g}$ of $N$. sativa seeds were grinded, poured into the flask mixed with $200 \mathrm{ml}$ of ethanol $(95 \%)$ in a concentration of $1: 10(\mathrm{~W}: \mathrm{V})$ in a cooled site, then stirred for 1 hour using a blender, and kept in refrigerator overnight then filtered using gauze and whatman filter paper No.1. The oil was isolated according to Ghourchian et al. (28) with some modifications by hexane using Soxhlet apparatus. The resulting mixture was collected in a separator funnel and kept in cold place overnight, collect the oil layer and stored in a sealed vial dark colored at $4{ }^{\circ} \mathrm{C}$. In order to evaluate the scolicidal effects of $N$. sativa seed's oil, gradient concentrations of oil extract were prepared as following 20, $25,30,35,40,45,50,55$ and $60 \mu \mathrm{l}$ of oil / $\mathrm{ml} \mathrm{PBS} \mathrm{(vol/vol)}$ using DMF (Dimethyl formamide) as a solvent, in addition to negative (protoscolices in $\mathrm{PBS}$ at $\mathrm{pH} 7.4$ ) and positive (protoscolices in 20\% hypertonic saline) control group. Each concentration was put $2 \mathrm{ml}$ in Siliconized test tube, then $0.2 \mathrm{ml}$ of protoscolices suspension (about 15000 PSC) were added to each tube, mix gently and incubated at $37^{\circ} \mathrm{C}$ for times interval $(5,10,15,20,25,30,35$, and $40 \mathrm{~min}$.). the viability of protoscolices were determined depending on reaction with vital stain $(0.1 \%$ aqueous eosin) and flame cells activity (29). Three replicates for each treatment were applied, $\mathrm{LC}_{50}$ and $\mathrm{LC}_{90}$ for extract was determined according to protoscolices viability. Furthermore, negative control group was protoscolices treated with buffer phosphate solution only while positive control group was protoscolices treated with $20 \%$ hypertonic saline solution.

\section{Biochemical studies}

$20 \mu \mathrm{l}$ of suspended protoscolices in BPS ( $\mathrm{pH} 7.2$ ) were put on glass slide, stained with aqueous eosin $(0.1 \%)$, spread, covered with cover glass, scanned for the number of vital protoscolices, 1500 vital protoscolices / $20 \mu$, the volume then was adopted for the subsequent study. Stock solution of $1000 \mu \mathrm{l}$. sativa seed's oil $/ \mathrm{ml}$ of the solvent (DMF) were prepared, then graduated concentration of the oil were prepared $(20,25,30,35,40,45,50,55$ and 60 $\mu \mathrm{l} / \mathrm{ml}$ PBS). Prepared E. granulosus protoscolices were added to each treatment group. $0.2 \mathrm{ml}$ of the prepared suspension were treated with $\mathrm{LC}_{50}(40 \mu \mathrm{l} / \mathrm{ml})$ of $N$. sativa oil extracts for $10 \mathrm{~min}$, the mixtures then were precipitated 
using MSE (super speed ultracentrifuge) at $10000 \mathrm{rpm}$. for 10 minutes. Sediments were washed with distilled water several times at $8^{\circ} \mathrm{C}$, centrifuged using the previous method, the protoscolices sediment were collected, crushed by 1 gram parasites : $5 \mathrm{ml}$ of 50 millimolar trichloro acetic acid (TCA) solution at $\mathrm{pH} 7.2$ using ultrasonic disintegration (Andreas Hettich, Germany) being crude homogenate (crude extract), the protoscolices were further centrifuged in ice bath (30), deep freeze for subsequent biochemical studies.

\section{Carbohydrates}

Herbert et al. (31) method was applied to estimate carbohydrates concentration in the extract. Absorbance was measured at $488 \mathrm{~nm}$ depending on carbohydrate standard curve that has been prepared different concentrations of glucose.

\section{Total proteins}

Lowry et al. (32) colorimetric method used to evaluate protein concentration. Folin Ciocalteus Reagent react with protein to produce blue complex in alkaline medium, absorbance measured at $750 \mathrm{~nm}$. Concentration of protein was estimated using protein standard curve applied by bovine albumin.

\section{Separation of nucleic acids from E. granulosus protoscolices}

Quantitative determination of nucleic acids (DNA and RNA) was determined according to Schneider's (33) method as available materials in our laboratories. Protoscolices extract was washed two times with ethyl alcohol (95\%) to discard lipids, $1.3 \mathrm{ml}$ of distilled water and $1.3 \mathrm{ml}$ of $10 \%$ TCA were added to the sediment, the mixture then heated at $90 \mathrm{C}^{\circ}$ for 15 minutes with shaking from time to time. In this step protoscolices proteins were disposed. The mixture then precipitated using cooled centrifuge $(10000 \mathrm{rpm})$ for 10 minutes. Filtrate kept away as filtrate (1), the sediment was then suspended again in 2.5 $\mathrm{ml}$ of $5 \% \mathrm{TCA}$, and then separation was performed using the formerly used method to gain filtrate (2). concentration of nucleic acids in the filtrates was assessed.

\section{Deoxyribonucleic acid (DNA)}

DNA concentration was estimated utilizing DNA calibration curve, that already prepared using calf thymus DNA. Absorbance of blue color sample was measured spectroscopically at $600 \mathrm{~nm}$ (33).

\section{Ribonucleic acid (RNA)}

Concentration of RNA was estimated in each sample quantitatively by measured the absorbance of green color sample at $660 \mathrm{~nm}$, then rely on RNA calibration curve that had been prepared using yeast RNA (33).

\section{Statistical Analysis}

In the present research, all experiments were accomplished in triplicate. Data analysis was carried out using SPSS statistical package version 19), which was sought to analyze the data by computer. Paired-Samples $\mathrm{T}$ Test, Two-Way ANOVA and Duncan test were used to analyze the differences between treatment and control groups. All differences were considered as significant statistically at $\mathrm{P} \leq 0.05$ (34).

\section{Results}

In the present work, essential oil of $N$. sativa seed was extracted, its scolicidal activity against Echinococcus granulosus protoscolices was tested. Different concentrations of Nigella sativa seed's oil following different incubation times interval were applied to estimate the lethal concentration of $N$. sativa oil for $50 \%$ of protoscolices $\left(\mathrm{LC}_{50}\right)$. Table 1 showed that the viability of treated protoscolices was decreased with the concentration increase, for example, treating protoscolices with $55 \mu 1 / \mathrm{ml}$ ( $\mathrm{vol} / \mathrm{vol}$ ) of oil was reducing protoscolices survival to $34.66 \pm 1.2 \%, 12.0 \pm 0.57 \%, 2.66 \pm 0.33 \%$ and $0 \%$ after 5,10 , 15 and $20 \mathrm{~min}$ of treatment respectively; while $82.67 \pm 1.45 \%, \quad 74.33 \pm 0.33 \%, \quad 67.67 \pm 1.2 \%, \quad 53.67 \pm 1.2 \%$, $37.33 \pm 0.33 \%, \quad 19.67 \pm 1.2 \%, \quad 7.67 \pm 1.2 \% \quad$ and $0 \% \quad$ of protoscolices were survive for treating with $20 \mu \mathrm{l} / \mathrm{ml}$ after $5,10,15,20,25,30,35$ and $40 \mathrm{~min}$ of exposure respectively. On the other hand, treating protoscolices with $60 \mu \mathrm{l} / \mathrm{ml}$ seed's oil for $10 \mathrm{~min}$ were approximately eliminate all protoscolices. It seems that $\mathrm{LC}_{50}$ of seed's oil for E.g. protoscolices was $40 \mu \mathrm{l} / \mathrm{ml}$ after $10 \mathrm{~min}$ of brood, while $\mathrm{LC}_{90}$ was $55 \mu \mathrm{l} / \mathrm{ml}$ of the oil at the same incubation period (Figure 1).

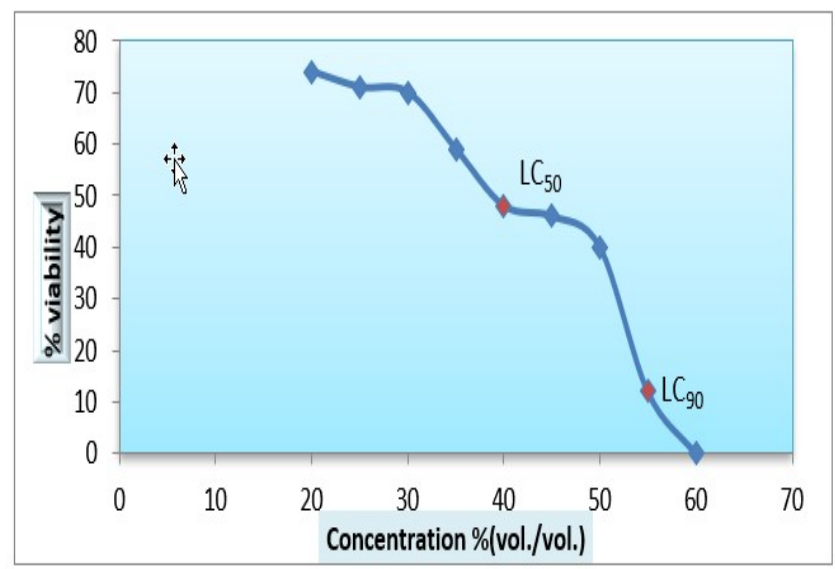

Figure 1: Effect of $\mathrm{LC}_{50}$ and $\mathrm{LC}_{90}$ of Nigella sativa seed's oil on the E.granulosus protoscolices. 
Table 1: The scolicidal effect of Nigella sativa seed's oil on the viability $\%$ of E. granulosus protoscolices at various concentrations following different exposure times in vitro, at $37^{\circ} \mathrm{C} \pm 2$ compared with negative and positive control groups (Duncan test at $\mathrm{P} \leq 0.05$ )

\begin{tabular}{|c|c|c|c|c|c|c|c|c|c|}
\hline \multirow{2}{*}{ Treatment } & \multirow{2}{*}{$\begin{array}{c}\text { Concentration } \\
\mu \mathrm{l} / \mathrm{ml}\end{array}$} & \multicolumn{8}{|c|}{ Mean viability $\%$ of Protoscolices \pm SE after: } \\
\hline & & $5 \mathrm{~min}$. & $10 \mathrm{~min}$. & $15 \mathrm{~min}$. & $20 \mathrm{~min}$. & $25 \mathrm{~min}$. & $30 \mathrm{~min}$. & $35 \mathrm{~min}$. & 40min. \\
\hline negative & \multirow{2}{*}{0} & $99.9 \pm 0.13$ & $99.9 \pm 0.1$ & $99.8 \pm 0.16$ & $99.8 \pm 0.13$ & $99.7 \pm 0.33$ & $99.7 \pm 0.33$ & $99.7 \pm 0.23$ & $99.6 \pm 0.33$ \\
\hline fluid $\mathrm{pH} 7.4$ ) & & I & A & A & $\mathrm{a}$ & A & A & & B \\
\hline $\begin{array}{l}\text { positive } \\
\text { control }\end{array}$ & \multirow[b]{2}{*}{20} & $426 \pm 088$ & $00 \pm 000$ & $00 \pm 00$ & $00 \pm 00$ & $00 \pm 0.0$ & $00 \pm 00$ & $00 \pm 00$ & $00 \pm 00$ \\
\hline \multirow{4}{*}{$\begin{array}{l}\text { control } \\
\text { (hypertonic } \\
\text { saline) }\end{array}$} & & $\mathrm{C}$ & A & A & A & A & A & A & A \\
\hline & 20 & $\begin{array}{c}82.67 \pm 1.45 \\
\mathrm{H}\end{array}$ & $74.33 \pm 0.33$ & $\begin{array}{c}67.67 \pm 1.2 \\
H\end{array}$ & $\begin{array}{c}53.67 \pm 1.2 \\
F\end{array}$ & $37.33 \pm 0.33$ & $19.67 \pm 1.2$ & $7.67 \pm 0.88$ & $0.0 \pm 0.00$ \\
\hline & & $81.66 \pm 0.33$ & $69.33 \pm 0.88$ & $60.0 \pm 1.0$ & $52.0 \pm 0.0$ & $34.66 \pm 0.66$ & $18.33 \pm 0.88$ & $4.0 \pm 0.57$ & $0.0 \pm 0.0$ \\
\hline & 25 & $\mathrm{H}$ & $\mathrm{H}$ & G & $\mathrm{F}$ & E & $\mathrm{D}$ & $\mathrm{C}$ & A \\
\hline \multirow{14}{*}{ 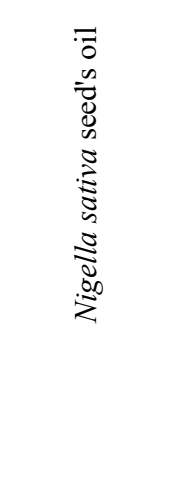 } & & $77.66 \pm 0.88$ & $69.0 \pm 0.88$ & $55.0 \pm 0.57$ & $47.33 \pm 1.33$ & $21.33 \pm 0.88$ & $10.33 \pm 1.32$ & $0.66 \pm 0.53$ & $0.0 \pm 0.0$ \\
\hline & 30 & G & G & $\mathrm{F}$ & E & D & $\mathrm{C}$ & B & A \\
\hline & 35 & $75.66 \pm 0.33$ & $59.33 \pm 0.33$ & $50.66 \pm 0.33$ & $38.0 \pm 0.57$ & $13.33 \pm 0.88$ & $3.33 \pm 0.88$ & $0.0 \pm 0.0$ & $0.0 \pm 0.0$ \\
\hline & 30 & G & $\mathrm{F}$ & E & $\mathrm{D}$ & $\mathrm{C}$ & B & A & A \\
\hline & 40 & $68.66 \pm 0.66$ & 48. $0 \pm 0.57 \#$ & $36.33 \pm 1.33$ & $20.0 \pm 0.57$ & $11.33 \pm 0.88$ & $0.0 \pm 0.02$ & $0.0 \pm 0.0$ & $0.0 \pm 0.0$ \\
\hline & & F & E & D & C & C & A & A & A \\
\hline & 45 & $55.33 \pm 1.2$ & $45.66 \pm 0.88$ & $14.0 \pm 0.0$ & $5.66 \pm 0.33$ & $0.3 \pm 0.3$ & $0.0 \pm 0.0$ & $0.0 \pm 0.0$ & $0.0 \pm 0.0$ \\
\hline & 45 & E & D & C & B & B & A & A & A \\
\hline & 50 & $47.66 \pm 0.88$ & $40.33 \pm 0.88$ & $10.33 \pm 0.33$ & $2.66 \pm 0.66$ & $0.0 \pm 0.0$ & $0.0 \pm 0.0$ & $0.0 \pm 0.0$ & $0.0 \pm 0.0$ \\
\hline & 50 & D & C & C & B & A & A & A & A \\
\hline & 55 & $34.66 \pm 1.2$ & $12.0 \pm 0.57 \# \#$ & $2.66 \pm 0.33$ & $0.0 \pm 0.0$ & $0.0 \pm 0.0$ & $0.0 \pm 0.0$ & $0.0 \pm 0.0$ & $0.0 \pm 0.0$ \\
\hline & 55 & B & B & B & A & A & A & A & A \\
\hline & 60 & $16.33 \pm 0.88$ & $0.0 \pm 0.3$ & $0.0 \pm 0.0$ & $0.0 \pm 0.0$ & $0.0 \pm 0.0$ & $0.0 \pm 0.0$ & $0.0 \pm 0.0$ & $0.0 \pm 0.0$ \\
\hline & 60 & A & A & A & A & A & A & A & A \\
\hline $\mathrm{F}$ & & 759.893 & 2217.512 & 2958.967 & 2285.507 & 2925.127 & 1251.373 & 5696.653 & 28383 \\
\hline
\end{tabular}

Significant at $\mathrm{P} \leq 0.05$, different letters vertically means significant difference, Each test tube was contained $\approx 15000$ protoscolices at zero time, Three replicates were applied for each treatment, Viability $\%$ at zero time was considered as $100 \%$, Initial number of protoscolices used in each treatment were $\approx 1500$ protoscolices $/ 20 \mu \mathrm{l}$, \# lethal concentration $50\left(\mathrm{LC}_{50}\right)$, \#\# lethal concentration $90\left(\mathrm{LC}_{90}\right)$.

Statistical analysis using Two-Way ANOVA and Duncan test was showed significant different between protoscolices viability $\%$ before and after treatment at $\mathrm{P} \leq 0.05$. It is seemed that reduction percentage in viability $\%$ was inversely proportional to the seed's oil concentration and exposure time. Ultimately, mean reduction percentage in viability was $100 \%$ as shown in table 1 .

Viability signs those adopted to evaluate the alive protoscolices were showed obvious different between protoscolices groups those treated with $N$. sativa oil and those in negative control group, especially after staining with the vital stain (red pigmentation in aqueous eosin $0.1 \%$ ), breakdown of flame cells movement and so that the peristaltic movement of the whole organisms those treated with the scolicidal oil (Figure 2).

Evaluation of protoscolices biomolecules after treating with Lethal concentration for $50 \%\left(\mathrm{LC}_{50}\right)$ of Nigella sativa seed's oil were made according to Herbert et al. (31), Lowry et al. (32) colorimetric and Schneider (33) method colorimetric method and compared with that of negative non-treated control group as in table 2, there were a significant $\mathrm{P} \leq 0.05$ decreased in the biomolecules contents of E. granulosus protoscolices with $\mathrm{LC}_{50}$ treated group compared with untreated group using Paired-Samples $\mathrm{T}$ Test.

\section{Discussion}

Antimicrobial properties of remedial herb medicines had been logically revealed in experiments with their oils, aqueous or alcoholic extracts, and other constituents (35). Clinically, albendazole was naturally used to treat echinococcosis with or without surgery, however, its severe side effects and poor solubility limit its application (36). The results revealed viability \% of protoscolices treated with $20 \%$ hypertonic saline solution (actually used in our hospital) for 5 minutes was $43 \%$, whereas, $16 \%$ of protoscolices were viable when treated with $60 \mu \mathrm{l} / \mathrm{ml}$ of 
seed's oil at the same time. The result of the present study was coming agree with that of Keyhani et al. (37), those concluded that scolicidal concentration of $20 \%$ hypertonic saline (the positive control in the present study) was terminate protoscolices viability $100 \%$ after $10 \mathrm{~min}$ of application. The same result is reviled in our work when $E$. granulosus protoscolices were treated with $60 \% \mathrm{~N}$. sativa seed's oil. Therefore, the scolicidal activity of seed's oil at the concentrations $60 \%$ after 10 min of incubation was approximately similar to that of positive control, whereas, the viability percentage was higher than $60 \%$ seed's oil at 5 min which indicate it is more active against protoscolices than our surgically used. It was proved to have inhibitory effects against E.granulosus that agree with Ali et al. (17).

Recently, N.sativa seeds oil has an effective antimicrobial activities considering their low coasty and good safety products (37). Agrawal et al. (38) manifested significant $N$. sativa seed's oil antihelmintic activity against some pathogenic nematode and cestode. Thymoquinone has hepatoprotective properties due to its antioxidant activity (28). Either whole seeds or fixed and essential oils have therapeutic effects on respiratory symptoms (28) The oil extract of Nigella sativa seeds have a clear impact in inhibiting protoscolices viability that agree with Mahmoudvand et al. (10). However, further studies will be required to approve these results by inspecting other derivatives of $N$. sativa and comparing with its active constituents in the in vitro and in vivo model and to estimate its mode of actions.

Generally, different concentrations of $N$. sativa oil tested in the present work were proved to have significant scolicidal effects at $\mathrm{P} \leq 0.05$. However, an ideal scolicidal agent is defined by its potency at lower concentrations, high efficacy in a shortest time of exposure, stability in the presence of cystic fluid, scolicidal ability inside a cyst, lower toxicity, higher availability, and ability to be prepared rapidly. Therefore, evolution of new scolicidal agents with higher efficacy and low or no local or systemic side effects is insistent need for surgical hydatidosis success.

Biochemical substances (metabolites) within hydatid cysts play definitive role in the metabolism, physiology and immunology of cystic echinococcosis $(39,40)$. This study observed decreased in carbohydrate, protein and nucleic acids (DNA and RNA) concentrations when treated with $\mathrm{LC}_{50}$ of seeds oil compared with non-treated group in which carbohydrate, proteins, DNA and RNA concentration was agree with AL-Abady (41) and Barazesh et al (42) in untreated group. There is significant $\mathrm{p} \leq 0.05$ relationship between metabolites quantities in E.granulosus protoscolices before and after treated with $N$. sative seed's oil.

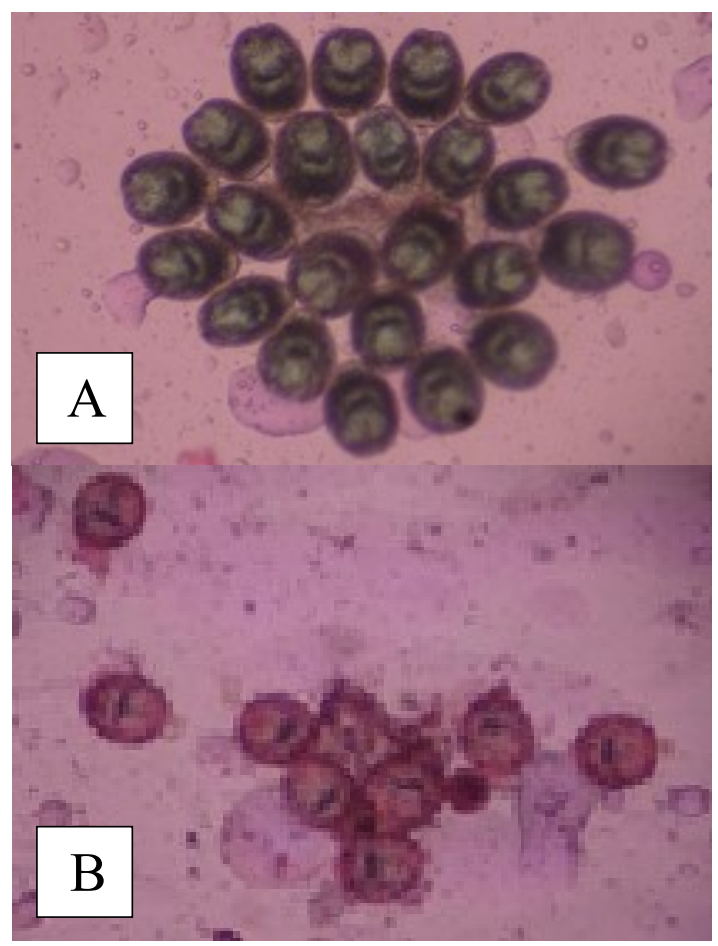

Figure 2: A; Living protoscolices of hydatid cyst in negative control group (note green color of vital protoscolices). B; note the red color of dead protoscolices those treated with $60 \%$ of $N$. sativa oil for $10 \mathrm{~min}$. (40X).

Table 2: Concentration of biomolecules in E. granulosus protoscolices after treating with Lethal concentration for $50 \%\left(\mathrm{LC}_{50}\right)$ of Nigella sativa seed's oil compared with negative control group

\begin{tabular}{lccccc}
\hline Biomolecule & $\begin{array}{c}\text { Mean concentration in group } \\
\text { treated with } \mathrm{LC}_{50} \text { of } N . \\
\text { sativa } \text { oil } \pm \text { S.E }\end{array}$ & $\begin{array}{c}\text { Mean concentration in } \\
\text { negative control } \\
\text { group } \pm \text { S.E }\end{array}$ & T value & DF & P value \\
\hline Carbohydrates $(\mu \mathrm{g} / \mathrm{ml})$ & $58.33 \pm 2.33$ & $62.66 \pm 2.33$ & -6.50 & 2 & 0.023 \\
Proteins $(\mathrm{mg} / \mathrm{dl})$ & $15.34 \pm 0.05$ & $31.0 \pm 1.03$ & -24.90 & 2 & 0.002 \\
DNA $(\mu \mathrm{g} / \mathrm{ml})$ & $18.19 \pm 0.1$ & $23.43 \pm 0.27$ & -36.10 & 2 & 0.001 \\
RNA $(\mu \mathrm{g} / \mathrm{ml})$ & $64.48 \pm 0.3$ & $82.96 \pm 0.36$ & -33.79 & 2 & 0.001 \\
\hline
\end{tabular}

Negative control group $=$ protoscolices in PBS ( $\mathrm{pH}$ 7.4), Significant at $\mathrm{P} \leq 0.05$. 


\section{Conclusion}

The present study demonstrated oil extract of $N$. sativa seed have effective scolicidal activity against protoscolices of Echinococcus granulosus in vitro, as well as, decrease biomolecules (protein, carbohydrate and nucleic acids) concentration of treated protoscolices. Further studies could be applied to check the ability of N.sativa seeds oil to inhibit growth of the hydatid cysts in vivo.

\section{Acknowledgements}

I extend my thanks and gratitude to Dr. Marwa Hashim Hamoushi for her support throughout the research period.

\section{References}

1. Khalf MS, Al-Faham MA, Al-Taie LH, Alhussian HA. Genotyping of Echinococcus granulosus in Samples of Iraqi Patients. J Pharm Bio Sci. 2014;9(3):06-10. Doi:10.9790/3008-09320610

2. AL-Jobori KMM, Faraj AA, Witwit NM. Inhibitory effectiveness of musk on viability of protoscolices of hydatid cysts. Int J Curr Microbiol App Sci. 2016;5(4): 998-1006. doi: 10.20546/ijcmas.2016.504.114.

3. Grubor NM, Jovanova-Nesic KD, Shoenfeld Y. Liver cystic echinococcosis and human host immune and autoimmune follow-up: A review. World J Hepatol. 2017;9(30):1176-1189. doi:10.4254/wjh.v9.i30.1176

4. Mousavi SR, Khoshnevis J, Kharazm P. Surgical treatment of hydatid cyst of the liver: Drainage versus. Omentoplast. 2005;4(4):272-274 doi:10.1016/s1665-2681(19)32051-4 .

5. Patkowski W, Grąt M, Krasnodębski M, Krawczyk M. Surgical treatment of hepatic Echinococcus granulosus. Przegląd Gastroenterologiczny. 2017;3(3):199-202.doi:10.5114/pg.2017.70473

6. Agnino A, Lanzone AM, Spira G, Anselmi A. Surgical treatment of left ventricular echinococcosis through the Heart Port technique. Inter Cardio Vascul Thor Surg. 2018;26(2):357-359. doi:10.1093/icvts/ivx290

7. Junghanss T, da Silva AM, Horton J, Chiodini PL, Brunetti E. Clinical management of cystic echinococcosis: state of the art, problems, and perspectives. Am J Trop Med Hyg. 2008;79(3):301-311. doi:10.4269/ajtmh.2008.79.301

8. Brunetti E, Kern P, Vuitton DA. Expert consensus for the diagnosis and treatment of cystic and alveolar echinococcosis in humans. Acta Tropica.2010;114(1):1-16. doi:10.1016/j.actatropica.2009.11.001

9. McManus DP, Zhang W, Li J, Bartley PB. Echinococcosis. Lancet. 2003;362(9392):1295-1304. doi:10.1016/s0140-6736(03)14573-4

10. Mahmoudvand H, Dezaki ES, Kheirandish F, Ezatpour B, Jahanbakhsh S, Harandi MF. Scolicidal effects of black cumin seed (Nigella sativa) essential oil on hydatid cysts. Korean J Parasitol. 2014;52(6): 653-659. doi:10.3347/kjp.2014.52.6.653

11. Mahmoudvand H, Harandi MF, Shakibaie M, Aflatoonian MR, ZiaAli N, Makki MS, Jahanbakhsh S. Scolicidal effects of biogenic selenium nanoparticles against protoscolices of hydatid cysts. Int J Surg. 2014;12(5): 399-403. doi:10.1016/j.jisu.2014.03.017

12. World Health Organization (WHO). Echinococcosis. 8 February 2018.

13. SharafiS M, Sefiddashti R, Sanei B, Yousefi M, Darani HY. Scolicidal agents for protoscolices of Echinococcus granulosus hydatid cyst: Review of literature. J Res Med Sci. 2017;22(1):92. doi:10.4103/jrms.jrms_1030_16

14. Samuel F, Degarege A, Erko B. Efficacy and side effects of albendazole currently in use against Ascaris, Trichuris and hookworm among school children in Wondo Genet, southern Ethiopia. Parasitol Inter. 2014;63(2):450-455. doi:10.1016/j.parint.2013.10.014

15. Kaur S, Singhi P, Singhi S, Khandelwal N. Combination therapy with albendazole and praziquantel versus albendazole alone in children with seizures and single lesion neurocysticercosis: A randomized, placebo-controlled double-blind trial. Pediat Infect Dis J. 2009;28(5):403-406. doi:10.1097/inf.0b013e31819073aa

16. Adas G, Arikan S, Kemik O, Oner A, Sahip N, Karatepe O. Use of albendazole sulfoxide, albendazole sulfone, and combined solutions as scolicidal agents on hydatid cysts (in vitro study). World J Gastroenterol. 2009;15:1-112. doi:10.3748/wjg.15.112 .

17. Ali BH, Blunden G. Pharmacological and toxicological properties of Nigella sativa. Phytother Res. 2003;17:299-305. doi:10.1002/ptr.1309

18. Assi MA, Noor MHM, Bachek NF, Ahmad H, Haron AW, Yusoff MSM, Rajion MA. The various effects of Nigella Sativa on multiple body systems in human and animals. Pertanika journal of scholarly research reviews. 2016;2(3):1-19.

19. Erkan N, Ayranci G, Ayranci E. Antioxidant activities of rosemary (Rosmarinus Officinalis L.) extract, blackseed (Nigella sativa L.) essential oil, carnosic acid, rosmarinic acid and sesamol. Food Chem. 2008;110:76-82. doi:10.1016/j.foodchem.2008.01.058

20. Morsi NM. Antimicrobial effect of crude extracts of Nigella sativa on multiple antibiotics-resistant bacteria. Acta Microbiol Pol. 2000;49:63-74.

21. Khan MA, Ashfaq MK, Zuberi HS, Mahmood MS, Gilani AH. The in vivo antifungal activity of the aqueous extract from Nigella sativa seed. Phytother Res. 2003;17:183-186. doi:10.1002/ptr.1146 .

22. Zuridah H, Fairuz ARM, Zakri AHZ, Rahim MNA. Invitro antimicrobial activity of Nigella sativa against Staphyllococcus aureus, Pseudomonas Aerugenosa, Klebsiella pneumonia, Escherinchia coli and Bacillus cereus. Asian J Sci. 2008;7(3):331333. doi:10.3923/ajps.2008.331.333

23. Al-Jumaily EF, Al-Jumaily AJS. The chemical composition of the fixed and volatile oils of Nigella sativa L. and its physico-chemical properties. European J Pharmaceut Med Res. 2015;2(5):906-917.

24. Refik M, Mehmet N, Durmaz B, Eğri M. Determination of some biochemical parameters in hydatid cyst fluids. Erciyes Med J. 2002;24(1):10-13.

25. Frayha GJ, Haddad R. Comparative chemical composition of protoscolices and hydatid cyst fluid of Echinococcus granulosus (Cestoda). Inter J Parasitol.1980;10(5-6):359-364. doi:10.1016/00207519(80)90036-3

26. Taşkın AD, Aksoylar MY. Total lipid and total fatty acid percentages of immature stages and adults of Itoplectis melanocephala (Gravenhorst, 1829) (Hymenoptera: Ichneumonidae). Türk Entomol Derg. 2011: 35(4):641-649.

27. Smyth JD. Studies on tapeworm physiology. XI. In vitro cultivation of Echinococcus granulosus from protoscolex to the strobilar stage. Parasitol. 1967;57:111-133. doi:10.1017/s0031182000071936

28. Ghourchian A, Hajimehdipoor H, Ara L, Choopani R, Kamalinejad M, Salimzadeh A, Gachkar L, Malekfar M. Essential oil and fixed oil content of Nigella sativa after a traditional medicine processing: A comparative study. Biol Forum Interl J. 2016;8(2):120-125.

29. Smyth JD, Barrett NJ. Procedures for testing the viability of human hydatid cysts following surgical removal, especially after chemotherapy. Trans R Soc Trop Med Hyg. 1980;74(5):649-52. doi:10.1016/0035-9203(80)90157-1

30. Jankeer MH. Al-Hammoshi MH, Al-Juwary RS. Presence and properties of thymidine phosphorylase in Echinococcus granulosus protoscolices. Raf J Sci. 2013;24:1-11.

31. Herbert D, Philips PJ, Stance RE. Methods in microbiology. London: Academic Press; 1971. p 241- 245. doi:10.1016/s05809517(08)70641-x

32. Lowry OH, Roseberough NJ, Farr AL, Rondall RJ. Protein measurement with the folin-phenol reagent. J Biol Chem. 1951;193:265-275. 
33. Schneider WC. Determination of nucleic acid in tissues by pentose analysis. 1st ed. New York: Academic Press; 1957. p 680-684. doi:10.1016/s0076-6879(57)03442-4

34. Steel RGD, Torrie JH. Principles and procedures of statistics. New York: Mc Graw-Hill; 1998.

35. Tiwari V, Roy R, Tiwari M. Antimicrobial active herbal compounds against Acinetobacter baumannii and other pathogens. Frontiers in Microbiology. 2015;6:618.doi:10.3389/fmicb.2015.00618 .

36. Zhang F, Hu C, Cheng S, Wang S, Li B, Cao B, Fan H, Pan R, Yang $\mathrm{M}, \mathrm{Xu} \mathrm{Y}$. The Investigation of the Effect and Mechanism of Sophora moorcroftiana alkaloids in combination with albendazole on echinococcosis in an experimental rats model. J Evid Based Complementary Altern Med. 2018;1:1-10. doi:10.1155/2018/3523126

37. Keyhani A, Kareshk AT, Oliaei RT, Mahmoudvand H. Protoscolicidal effects and acute toxicity of essential oil and methanolic extract of Cuminum cyminum Seed's. Marmara Pharmaceut J. 2017;21(3):551557 .doi:10.12991/marupj.319204.
38. Agarwal R, Kharya MD, Shrivastava R. Antimicrobial and anthelmintic activities of the essential oil of Nigella sativa Linn. Indian J Exp Biol. 1979;17(11):1264-5.

39. Thompson RC., Lymbery AJ. Echinococcus and hydatid disease. 1st edition. Wallingford: CAB International;1995. p 122-135. doi:10.1017/s0022149x00014280

40. Sheriff DS, Fakhri SA, Kidwai FR. Lipid in hydatid fluid collected from lung and liver of sheep and man. J Helminthol. 1989;63:266268. doi:10.1017/s0022149x00009081.

41. AL-Abady FAM. biochemical profiles of hydatid cyst fluids \&protoscolies of Echinococcus granulosus of human and animal origin in Thi-Qar provinice southern of Iraq. [master's thesis]. College of Education: Thi-Qar University;2015.

42. Barazesh A, Sarkari B, Ebrahimi S, Hami M. DNA extraction from hydatid cyst protoscolices: Comparison of five different methods. Vet Worl. 2018;11:231-234. doi: 10.14202/vetworld.2018.231-234. 